\title{
Assessing the Hydrocarbon Prospectivity in the Nigeria Offshore West Delta Using Seismic Volume and Well Log Data
}

\author{
Emmanuel B. Umoren ${ }^{1} \quad$ Etim D. Uko ${ }^{2} \quad$ Kufre I. Udo ${ }^{3}$ \\ 1.University of Uyo, Uyo, Nigeria \\ 2.Rivers State University, Port Harcourt, Nigeria \\ 3.Federal University, Lokoja, Nigeria
}

\begin{abstract}
Evaluation of Z-Field prospect located in the western Niger Delta at a shallow water depth of about $100 \mathrm{~m}$ was carried out using 3-D seismic and well data. The aim of this study is to evaluate the hydrocarbon potential of the target bed (R01A reservoir) using checkshot, seismic and well log data. Results of the structural interpretation revealed extensional tectonics characterized by rollover structures which are bounded by regional and counterregional listric (growth) normal faults. These structural features are associated with normal deltaic progradation and are conspicuous throughout the whole delta province. A key finding of this study is that subsurface structures in the study area lack closure to accumulate hydrocarbon. This is attributed to the small throw of faults relative to sand thickness, causing a significant sand to sand juxtaposition across faults. Consequently, the R01A reservoir is interpreted as wet sand. A lack of amplitude coherence with structure provided additional validation of the interpreted wet sand scenario and above all, increased our confidence on the result.
\end{abstract}

Keywords: prospect evaluation, seismic and well log data, Niger Delta, structural interpretation, faults, horizons DOI: $10.7176 / \mathrm{JEES} / 9-10-06$

Publication date:October $31^{\text {st }} 2019$

\section{Introduction}

The Niger Delta basin has been the focus of hydrocarbon exploration since 1937 and exploration activities still continues to present day, many decades after first commercial crude oil discovery in 1956 at Oloibiri, Bayelsa State by Shell British Petroleum (Reijers, 2011). By today, the delta is covered by a dense grid of improved 2-D, 3-D and 4D seismic data, following rapid advances in seismic technology, therefore allowing for better imaging of the delta tectono-stratigraphic evolution. Though divided opinions abound on whether or not the Niger Delta is presently a matured hydrocarbon province or a Mid-life Basin, sustained exploratory efforts have continued to produce more discoveries of oil and gas beyond the onshore limits of the delta where early discoveries were made. The deepwater and ultra deepwater portions of the delta have attracted robust exploration interest in recent years and following continuing exploration, current reserves distribution statistics show that majority of proven reserves are located along the Niger Delta River, offshore Bight of Benin, Gulf of Guinea and the Bight of Bonny (Kadafa, 2012).

The study area is located in the Niger Delta Basin. The Niger Delta basin is a prolific hydrocarbon basin located in Southern Nigeria on the West African Atlantic coast and extends into the continental margins of the neighbouring Cameroun and Equatorial Guinea. The delta has a coastline of about $450 \mathrm{~km}$, which terminates at the mouth of Imo River (Kadafa, 2012). The Niger Delta Basin covers an area of approximately $300,000 \mathrm{~km}^{2}\left(\mathrm{Kulke}_{\mathrm{k}}\right.$ 1995 ), with a sediment volume of $500,000 \mathrm{~km}^{3}$ (Hospers, 1965) and a sediment thickness of over $10 \mathrm{~km}$ in the basin depocentre (Kaplan et al., 1994). About 2,370 $\mathrm{km}^{2}$ of the Niger Delta area is covered by rivers, creeks and estuaries. An estimated $8600 \mathrm{~km}^{2}$ is made up of stagnant swamps while the delta mangrove swamp runs through about $1900 \mathrm{~km}^{2}$, making it the largest mangrove swamp in Africa (Kadafa, 2012).

The Niger Delta is the leading petroleum producing basin in Africa and ranks among the world's most prolific petroleum-producing Tertiary deltas, comparable to the Alaska North Slope, the Mississippi, the Orinoco and the Mahakam deltas (Reijers et al., 1997). Figure 1 shows the location of the delta amongst the world petroleum producing deltas. Locally, the prospect is located in the western part of the Niger Delta Basin in Southern Nigeria and belongs to the conventional offshore domain. The study area is characterized by a shallow water depth of about $100 \mathrm{~m}$.

Overall, the Niger Delta Basin accounts for over ninety-per cent of Nigeria's crude oil, condensate and natural gas productions. Presently, petroleum remains the mainstay of Nigerian economy. Revenues accruable from these productions are the primary financier of the country's budget as Nigeria's national budgets are still being predicated on a benchmark price of a barrel of crude oil.

The aim of this study, however, is to evaluate the hydrocarbon potential of the study area using seismic and well data. The key objectives are geared towards prospect definition and evaluation of the study area. This will be achieved through well calibration, seismic interpretation (horizons and faults picking), building of time maps, building of velocity model, performing time to depth conversion and generation of attribute map. 


\section{GEOLOGY OF THE STUDY AREA}

The Niger Delta is situated in the Gulf of Guinea and extends throughout the Niger Delta Province as defined by Klett et al. (1997) with sedimentation patterns that reflect response to Basement Tectonism. From the Eocene to the present the delta has prograded south-westward forming depobelts (Figure 1) namely Northern Delta, Greater Ughelli, Central Swamp, Coastal Swamp, Shallow Offshore and Deepwater (Knox and Omatsola, 1989) that represent the most active portion of the delta at each stage of its development. These depobelts form one of the largest regressive deltas in the world with an area of some $300,000 \mathrm{~km}^{2}$ (Kulke, 1995), a sediment volume of $500,000 \mathrm{~km}^{3}$ (Hospers, 1965), and a sediment thickness of over $10 \mathrm{~km}$ in the basin depocentre (Kaplan, et al., 1994) The Tertiary section of the Niger Delta is divided into three formations, representing prograding depositional facies that are distinguished mostly on the basis of sand-shale ratios. The type sections of these formations are described in Short and Stauble (1967); Frankl and Cordy (1967) and Tuttle et al. (1999). These are from top to bottom, the Benin Formation made up of massive continental, fluviatile gravels and sands, up to 2000m thick; the Agbada Formation that is characterized by interbedded fluviatile, coastal, fluviomarine sands and marine shales measuring up to $5000 \mathrm{~m}$ thick and the Akata Formation that comprise massive, marine shales or clays with stringers of sands and silt with thickness in excess of $5000 \mathrm{~m}$. Together, they form a thick, overall progradational passive-margin wedge.

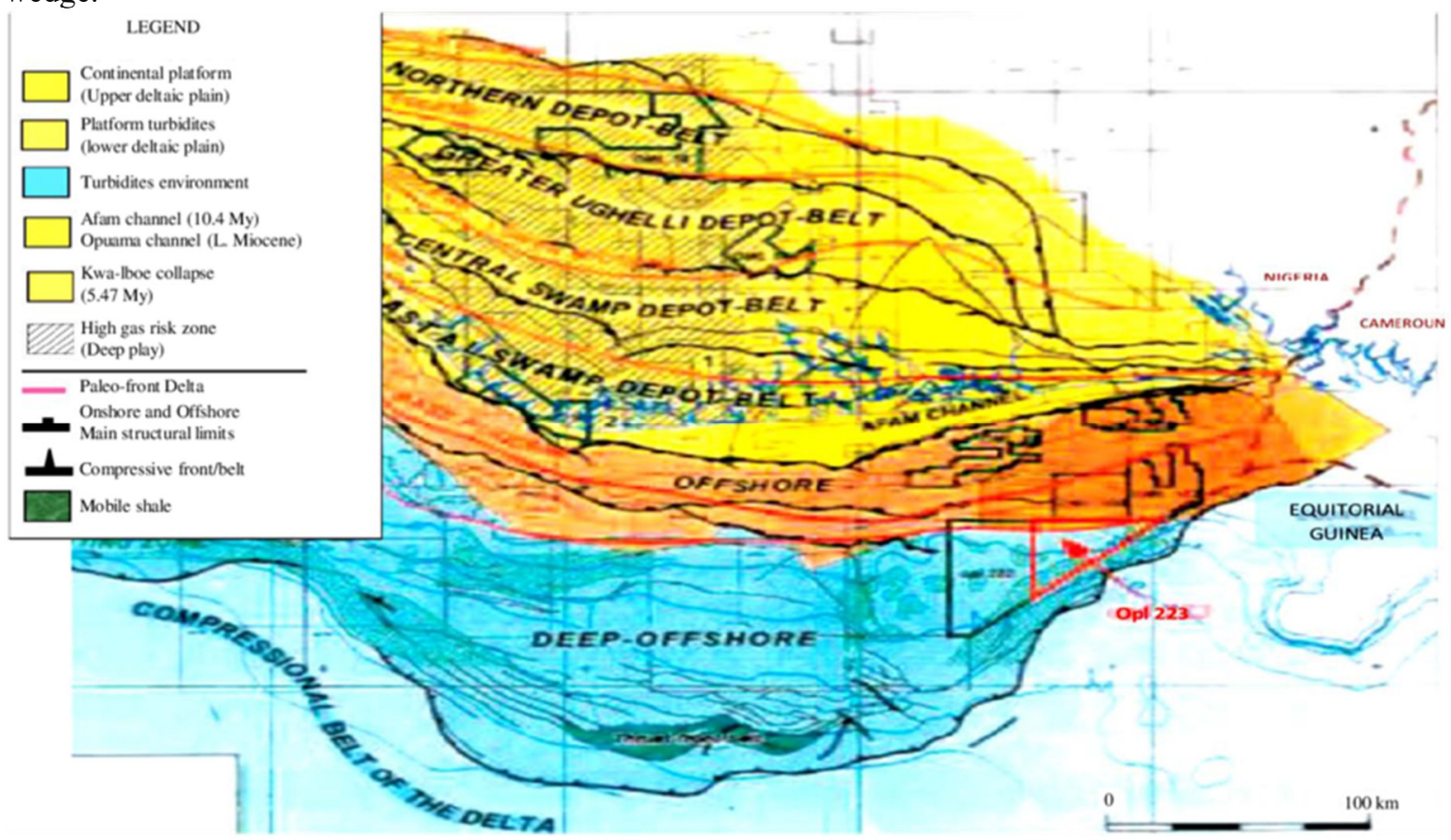

Figure 1: Niger Delta map showing all the depobelts.

(https://www.researchgate.net/profile/Lukumon_Adeoti/publication, retrieved on June 27, 2017)

\subsection{MATERIALS AND METHODS}

\subsection{Dataset Used:}

$3 \mathrm{D}$ seismic and well log data were employed to investigate the prospection of hydrocarbon potential of some wells in the arcuate Niger Delta. The $3 \mathrm{D}$ seismic volume was quality-controlled to determine its phase, frequency content and amplitude spectra. The phase of the data was determined through seismic to well calibrations as zero phase. The frequency content of the seismic volume was examined in order to determine the vertical resolution of the seismic data. Upon the investigation, it was found that the data has a mean frequency $(f)$ of $25 \mathrm{~Hz}$ at reservoir interval. An average velocity $(v)$ of $2460 \mathrm{~ms}^{-1}$ was also estimated from the sonic log in this interval. With these parameters, the wavelength $(\lambda)$ and vertical resolution of the seismic data were determined as follows:

$$
\begin{aligned}
& v=f \lambda \\
& \lambda=\frac{v}{f}
\end{aligned}
$$

Using Equation 2, wavelength was determined from frequency and average to be $98.4 \mathrm{~m}$. The value, $v$ represents the interval velocity of the layer, and $f$ is the mean frequency of the seismic data. 
The vertical resolution of a seismic data was measured in terms of its wavelength and was estimated to a quarter of the wavelength $\frac{\lambda}{4}$ i.e. $25 \mathrm{~m}$

A stratigraphic layer can be resolved in the seismic data only if the layer thickness is greater than a quarter of the wavelength $(\lambda)$. Hence, only a layer with thickness greater than $25 \mathrm{~m}$ was resolved. However, it was still possible to gain important information below this thickness $(25 \mathrm{~m})$ through quantitative analysis of the interference amplitude. A bed with $\lambda / 25$ in thickness may be detectable if its thickness cannot be determined from the wave shape. Event tuning - interference between seismic pulse representing the top of the reservoir and the seismic pulse representing the base of the reservoir, illustrated in Figure 2, would be produced by thin-layered reservoirs if the layer thickness is less than $25 \mathrm{~m}$. Constructive interference between the top and base of the layer may be observed between $\lambda / 2$ and $\lambda / 4$ as the amplitude increases and becomes larger than the real reflectivity. Similarly, tuning thickness, the maximum constructive interference occurred at $25 \mathrm{~m}$ (which corresponds to a quarter of the wavelength). Between $\lambda / 4$ and 0 , destructive interference was observed as amplitude decreases and approaches zero for layer thicknesses within this limits as shown in Figure 2.

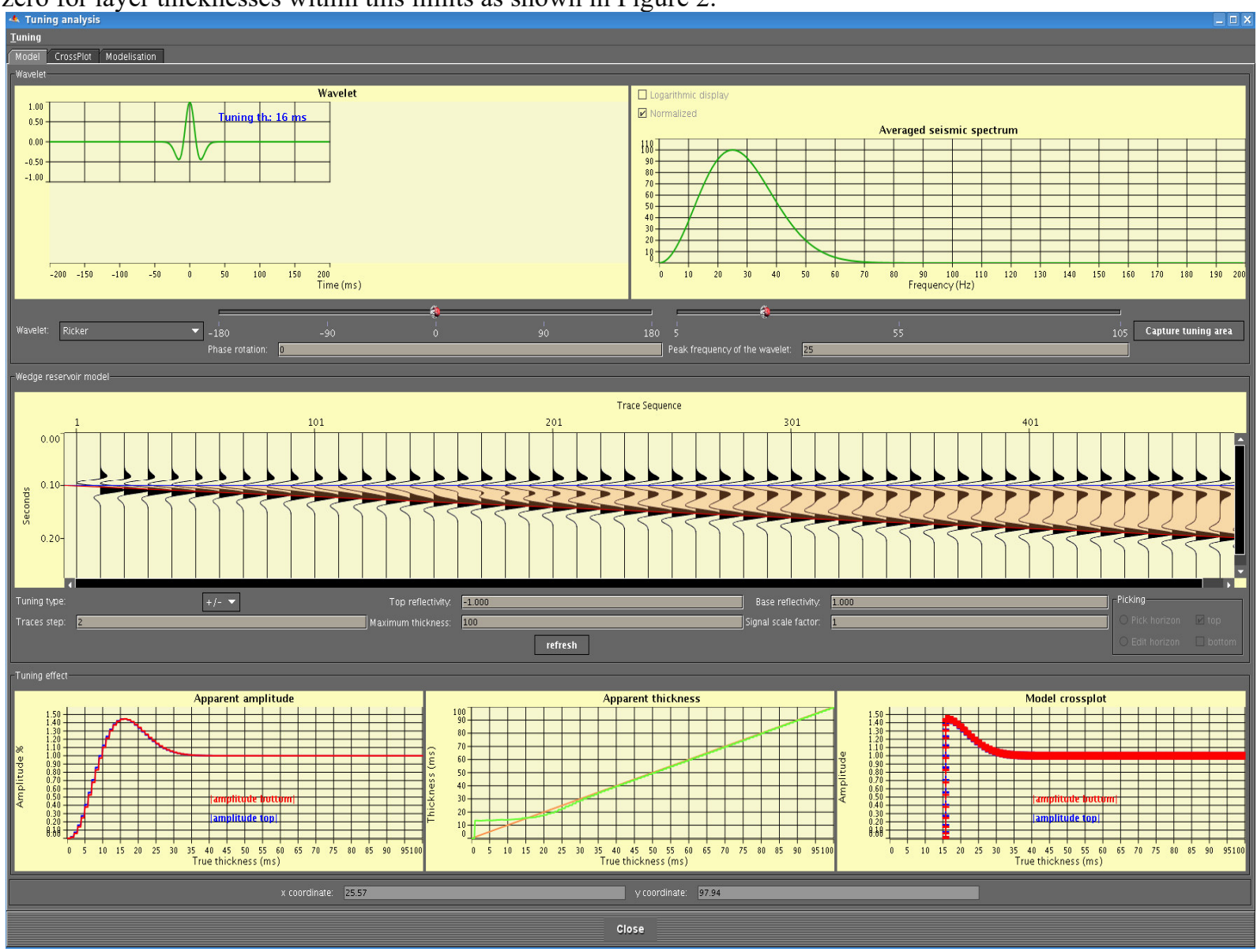

Figure 2: Tuning analysis plate showing seismic amplitude as a function of layer thickness for a given wavelength

\subsection{Well-to-Seismic Tie}

Surface-recorded seismic data compose of the largest database that can be used in reservoir development. However, seismic data have one shortcoming that can limit their usefulness - the reflection events used to map the seismic sequences and the seismic facies that describe the areal and vertical distributions of reservoir and sealing units are measured as functions of seismic traveltime, not as functions of depth. To understand reservoir performance, checkshot analysis was done to fine-tune the boundaries of these units in terms of depth. Thus, the concept of the velocity checkshot established time-depth calibration at the control wells so that surface-recorded seismic images can be reliably converted to the depth images that are needed to do reservoir volumetric calculations. Through checkshot-sonic integration illustrated in Figure 3, corrected sonic logs and accurate time-depth laws were obtained, based upon which impedance and reflectivity logs were computed to generate synthetic seismic traces. 


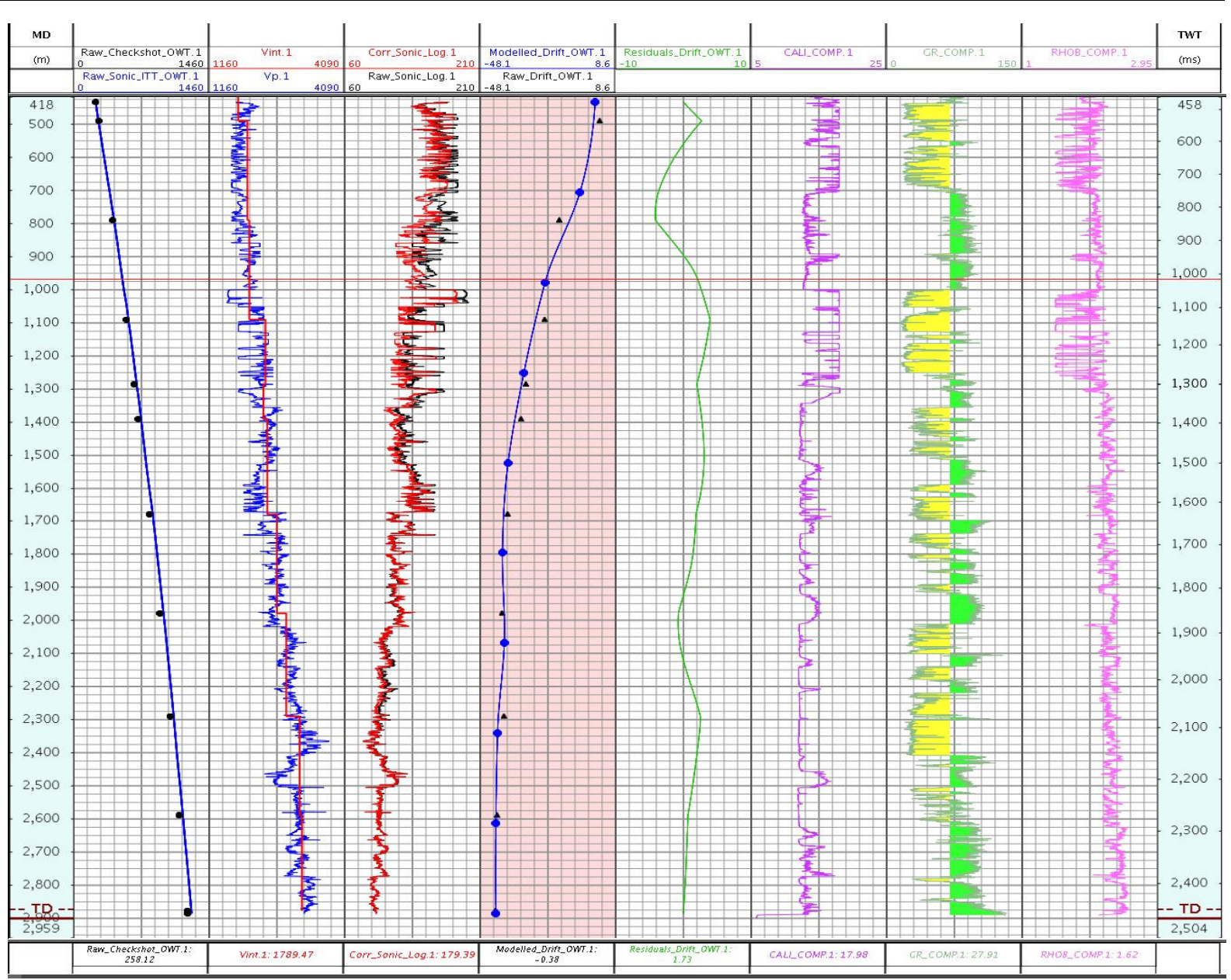

Figure 3: Checkshot-sonic calibration plate for well A

By using the well logs (sonic and density logs) from the control wells and wavelet extracted in the neighbourhood of each of the control wells or from the seismic volume, synthetic seismogram was generated to establish the desired relationship between seismic reflections and stratigraphy. The generation of synthetic seismogram was based on the convolutional model. This involved creating a reflectivity series in time (from calibrated sonic and density logs) and convolving it with the extracted wavelet plus noise (coherent and incoherent noise)

Mathematically, this can be represented by the expression given in Equation 3:

$T=W * R+N$

where $T$ is the seismic trace, $W$ is the source wavelet, $R$ is the reflection coefficient and, $N$ is noise (coherent and incoherent noise).

In order to minimize possible misty due to the poor quality of the seismic volume during seismic to well calibration, a suitable time window was chosen (1000 to $2400 \mathrm{~ms})$ to exclude the upper section of the seismic volume where noise was dominant as well as the lower part with weak reflections. As part of the quality control measures, only sonic logs corrected for the effect of drift via calibration with checkshots were used to generate the reflectivity logs. Seismic to well calibration on the two control wells was performed in order to accurately locate geologically relevant horizons before mapping. The seismic calibrations were therefore based on computed synthetics using calibrated checkshot-sonic and density logs from the reference wells, A and B. Four synthetic seismic traces were generated; one each for the two control wells using the wavelet extracted in the neighbourhood of wells and one each using a zero-phased Ricker wavelet at the data's mean frequency of $25 \mathrm{~Hz}$. Results of the calibrations showed that those obtained with Ricker wavelet were better than those computed using wavelets extracted at or around each of the control wells. Hence, computing synthetics using both wavelets allowed for comparison of the quality of the seismic to well calibrations. The fairly acceptable calibration obtained from synthetics using the wavelet extracted from the data can be attributed to distortions suffered by the extracted wavelets due to the presence of noise/multiples in the data. As a result, the wavelength is not a good representative of the seismic data. Conversely, Ricker wavelet which is a zero-phased mathematical wavelet does not suffer from similar distortion; hence its wavelength is a good representative of the wavelength of the seismic data. The wavelet extracted at or around well A and the corresponding synthetics is presented in Figure 3. Good seismic to well 
calibrations have been achieved with a time shift of $16 \mathrm{~ms}$ and $21 \mathrm{~ms}$ respectively. The synthetics also indicated the response for the top of the reservoir as a trough.

Resistivity and Gamma Ray logs were directly plotted on the seismic section to validate calibration as the quality of the seismic section and sonic logs used to generate synthetics are generally bad. Caliper logs indicate that the sonic logs suffer from borehole caving, poor coupling and possibly, cycle skipping.

The synthetics indicated that the top of the R01A reservoir in Figure 4 is trough. The calibration formed the first step in picking events. Horizons interpreted were composed of marine flooding surface and the top of the reservoir to be evaluated. The marine flooding surface was interpreted and picked as peak as indicated by synthetic seismogram. Good seismic to well ties provided an increased confidence in the interpretation. The horizons interpretation of the study area on the 3D seismic volume in Figure 4 is based on well to seismic calibrations.

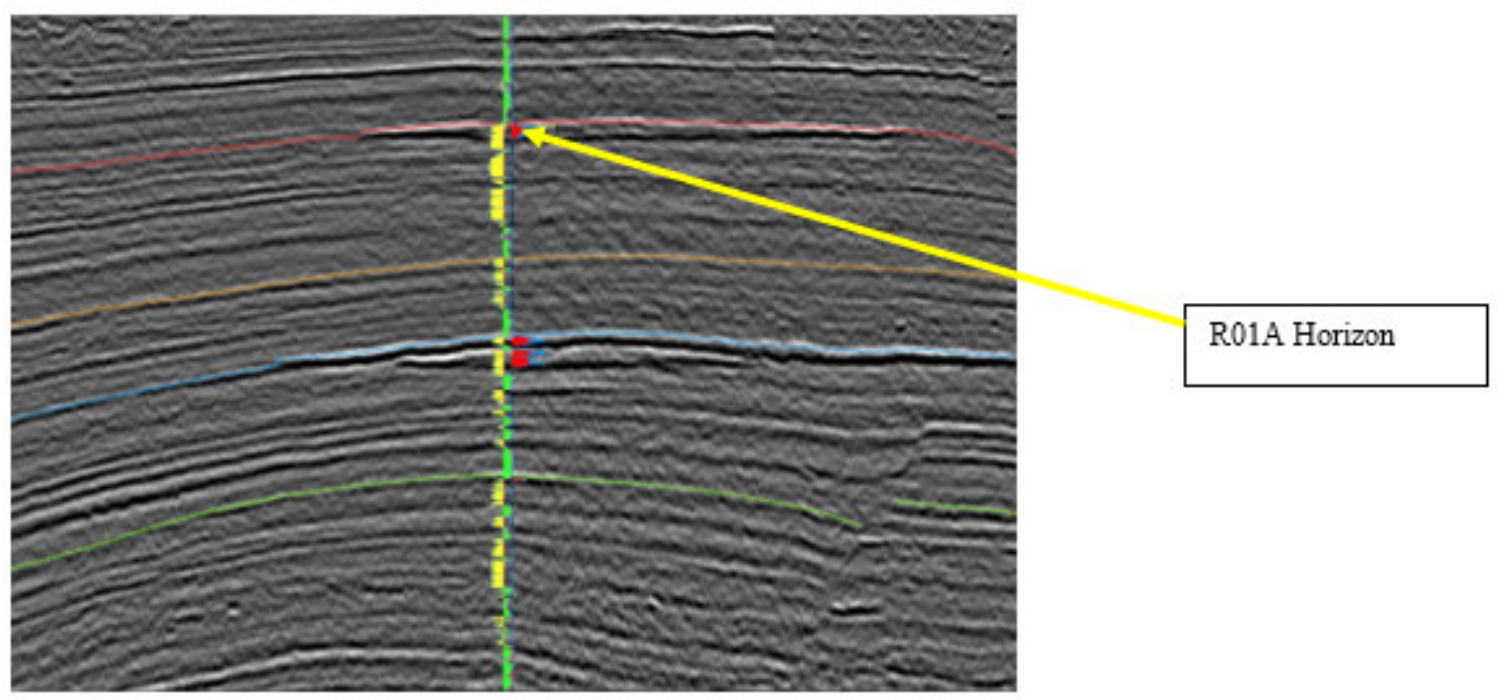

Figure 4: Seismic section showing interpreted horizons

\subsection{Results and Discussion}

\subsection{Reservoir Structure}

The prospect is found to be entrapped in a growth related structure. The trap is a two-way dip against three faults. The main risk associated with this trap is the non-sealing N60 fault. The trap definition is based on interpreted boundary faults that delineate the prospect as displayed in Figure 4. Seismic interpretation of the study area was completed based on seismic to well calibrations. These calibrations indicated that the top of the reservoir is a trough. The structural style of the study area is characterized by regional and counter regional listric growth faults and associated rollover structures. These listric growth faults are mainly structure bounding, therefore forming the boundary faults that delineate the prospect. The structural features are consistent with the faulting pattern conspicuous in extensional zone of the Niger Delta Basin, the location of this study as discussed in several leading publications (Weber, 1971; Evamy et al., 1978; Damuth, 1994).

A key finding of this study is that there is no closure in the study area due to fault seal failure. The N60 fault separating the prospect from field $\mathrm{C}$ in Figures 5 and 6 has a small throw (max. $30 \mathrm{~m}$ ) relative to the sand thickness (70m). As a result, there is a 40m sand to sand juxtaposition across the N60 fault. By implication, the reservoir is hydrodynamically connected to downdip of field $\mathrm{C}$ which is in the water leg. As no borehole exists in the study area, it is impossible to determine reliably the net-to-gross (NTG) ratio of the reservoir from which additional information could be extracted on any seal possibility by clay smearing and/or cataclastic gouge generation within the fault zone. More so, amplitude extracted from the top reservoir overlaid on structure depth map (Figure 7) indicates that amplitude distribution does not conform to structure. The amplitude expression is rather dispersive and regional in the study. The R01A reservoir is a trough as predicated by the seismic to well calibration. The $500 \mathrm{~m} \times 500 \mathrm{~m}$ grid basis in Figures 8 and 9 are associated with fault sticks as indicated by the red horizon. In other areas, picking of horizons was chosen to be confined by $250 \mathrm{~m} \times 250 \mathrm{~m}$ in order to define the prospect zone. In order to achieve fidelity in horizontal interpretation, marine flooding surface displayed as green on red horizontal surface in Figures 8 and 9 was delineated.

Isochron map was obtained after gridding and thereafter, isopach maps were generated with associated fault polygons. The structural and horizon interpretations are shown in Figures 7 to 13 are the results of the horizon and structural interpretation of the area. The curve in Figure 14 shows a quadratic function, indicating the polynomial time-depth function. However the curve increases proportionally when time and depth increase. The throw of the three faults upon which the closure $(1390 \mathrm{~m})$ is defined have been calculated indicated on the Depth structure map 
of Figure 13. The crest of the structure is located at $1234 \mathrm{~m}$.

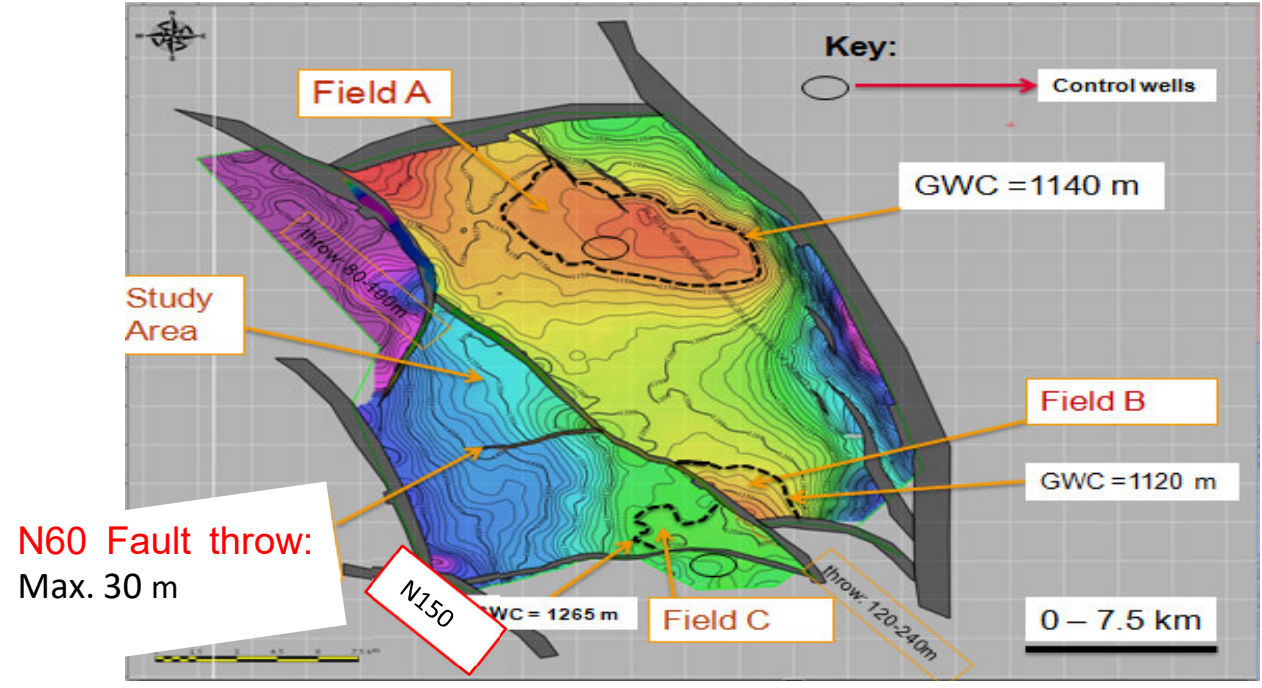

Figure 5: Top Reservoir Depth Structure Map (m) with fault boundaries, showing the 3 fields and their gas - water contact (GWC), as well as the throw of the faults delineating the prospect

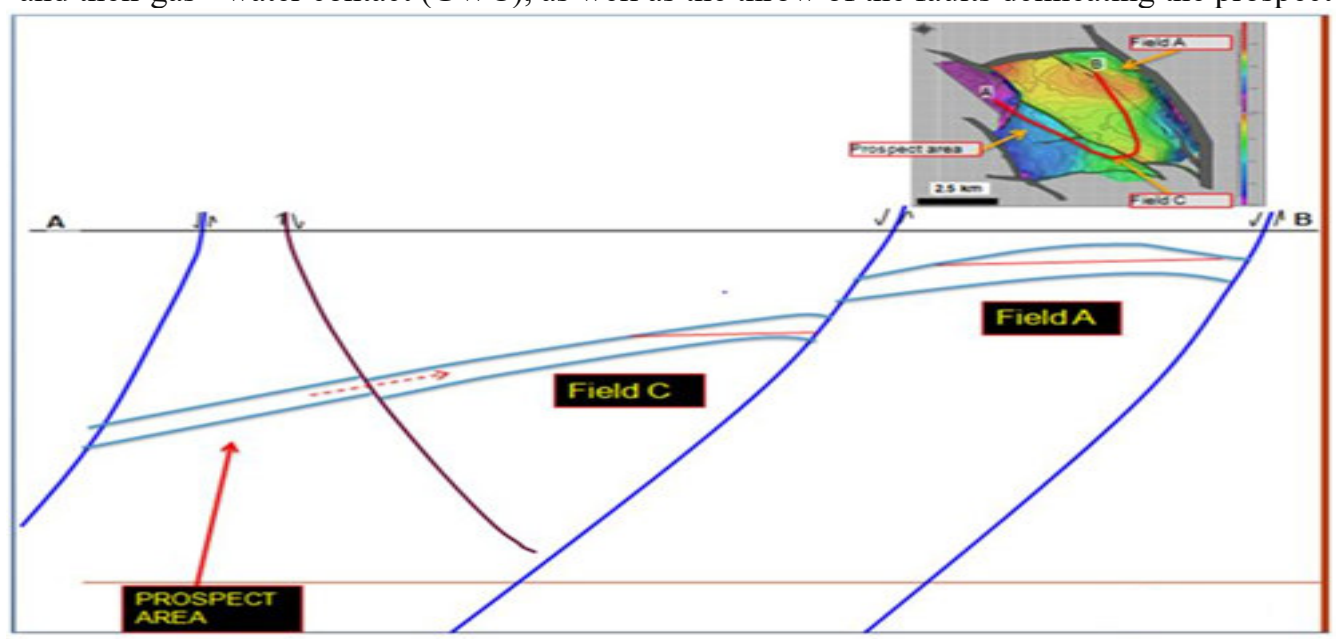

Figure 6: Structural cross-section of the study area

A

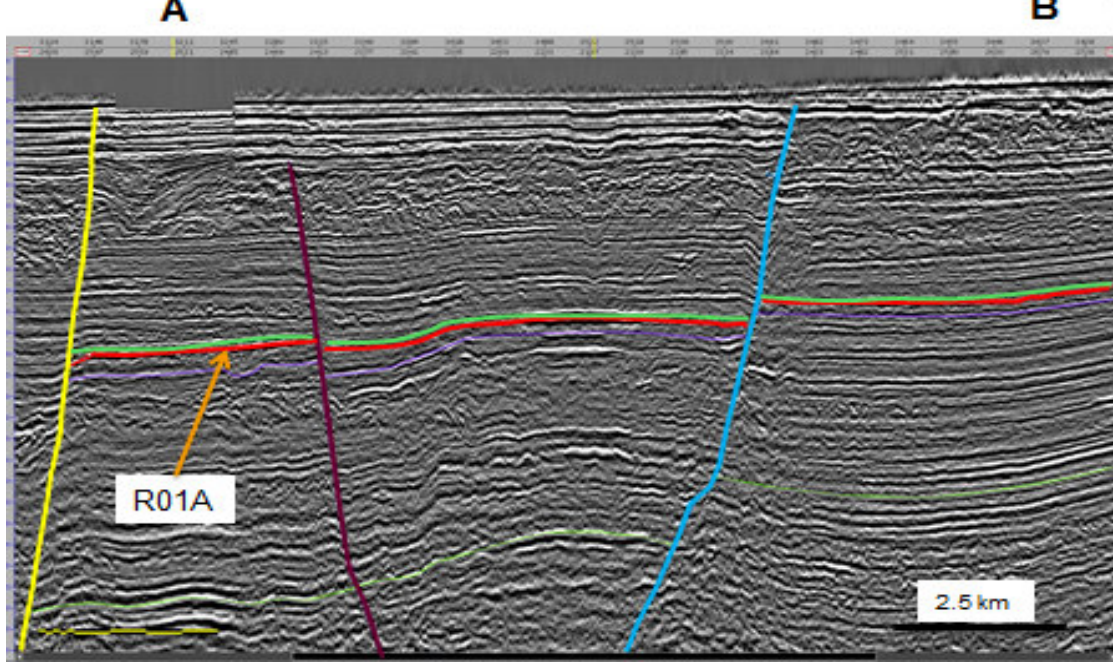

Figure 7: Interpretation with random line from B to A which shows the study area is characterised by regional and counter-regional growth faults which form boundary faults and consequently delineate the prospect. 

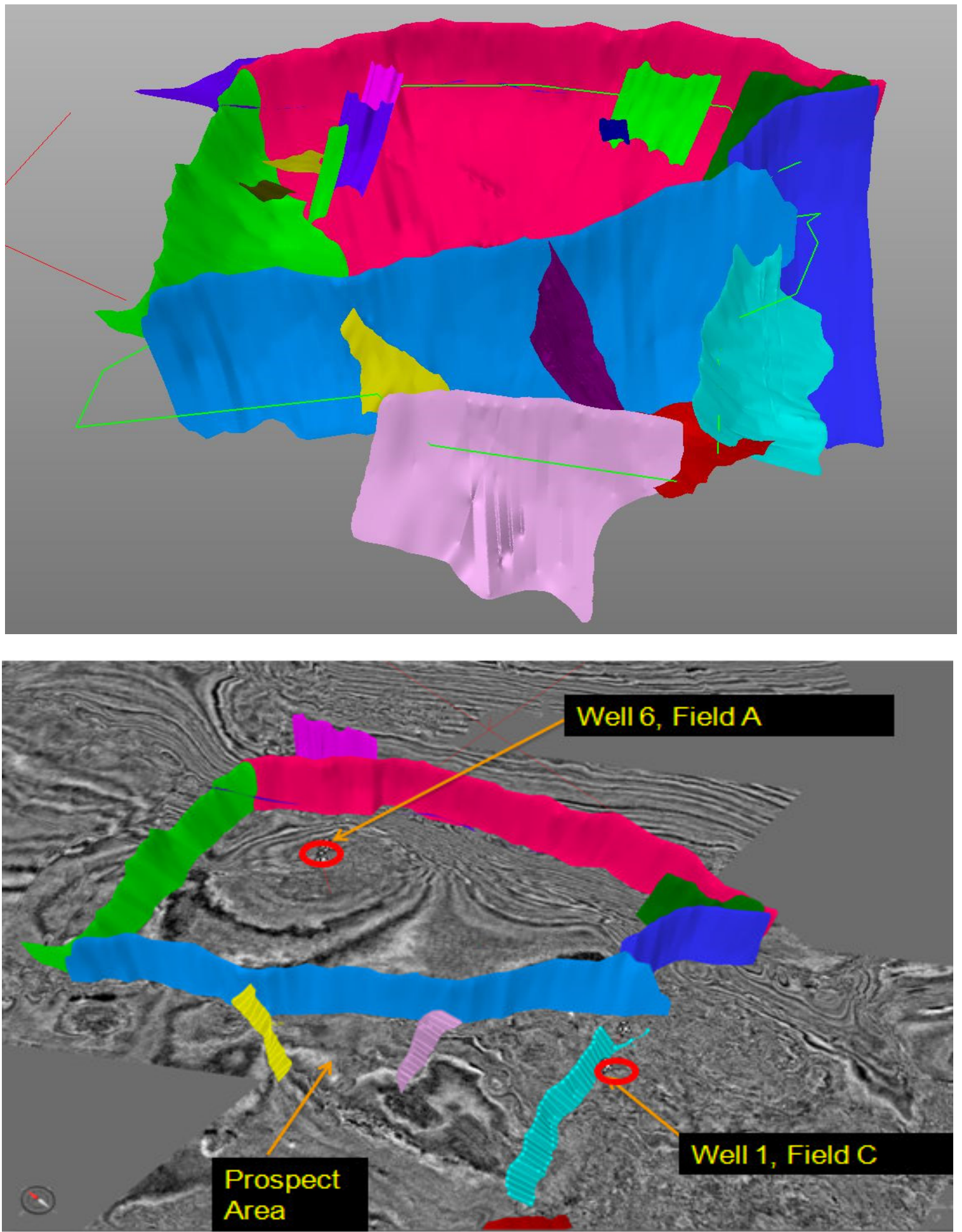

Figure 8: 3D view of interpreted boundary faults (top) and corresponding display on time slice (bottom), showing delineation of the study area 


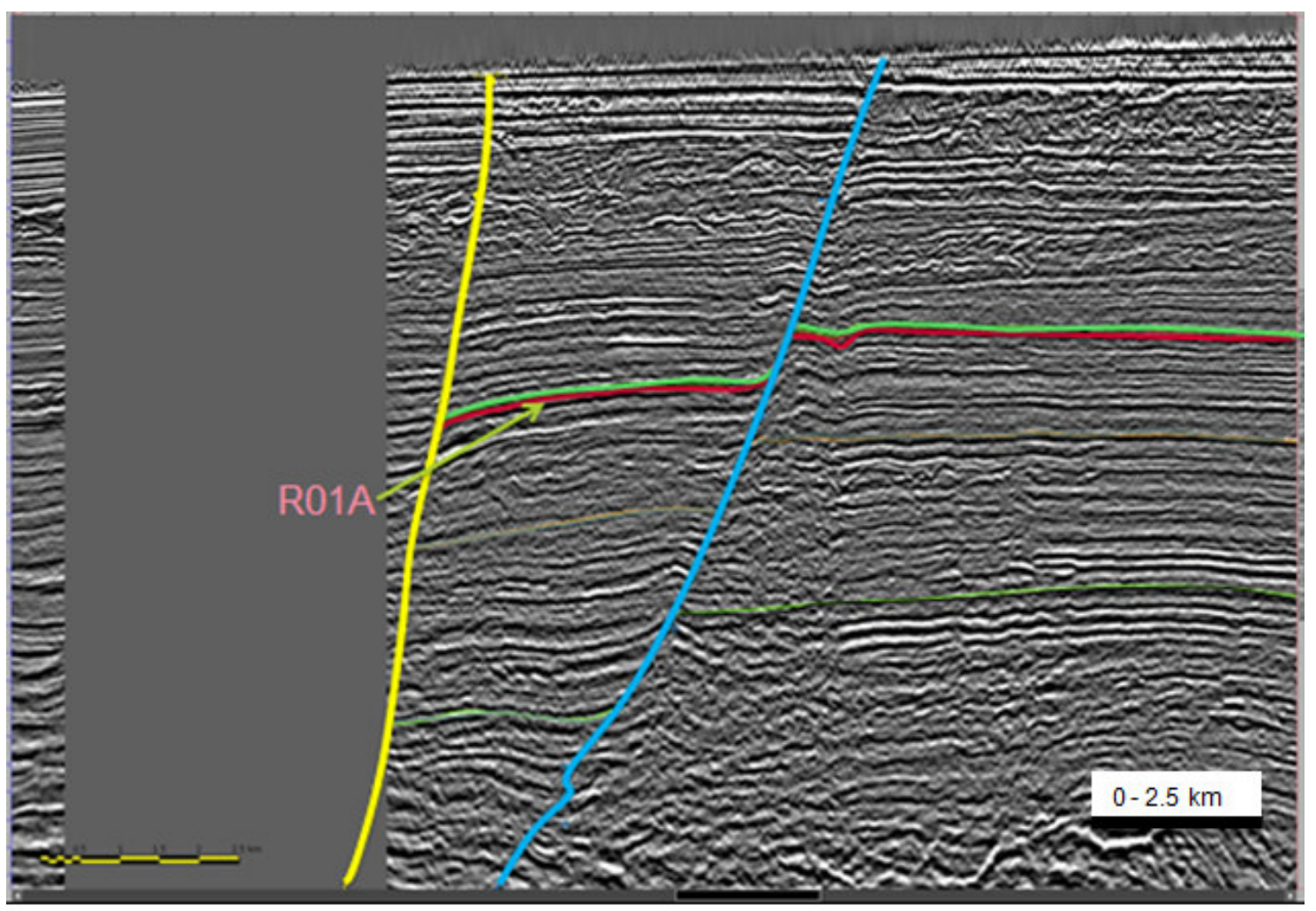

Figure 9: Crossline 3400m and R01A fault orientation 

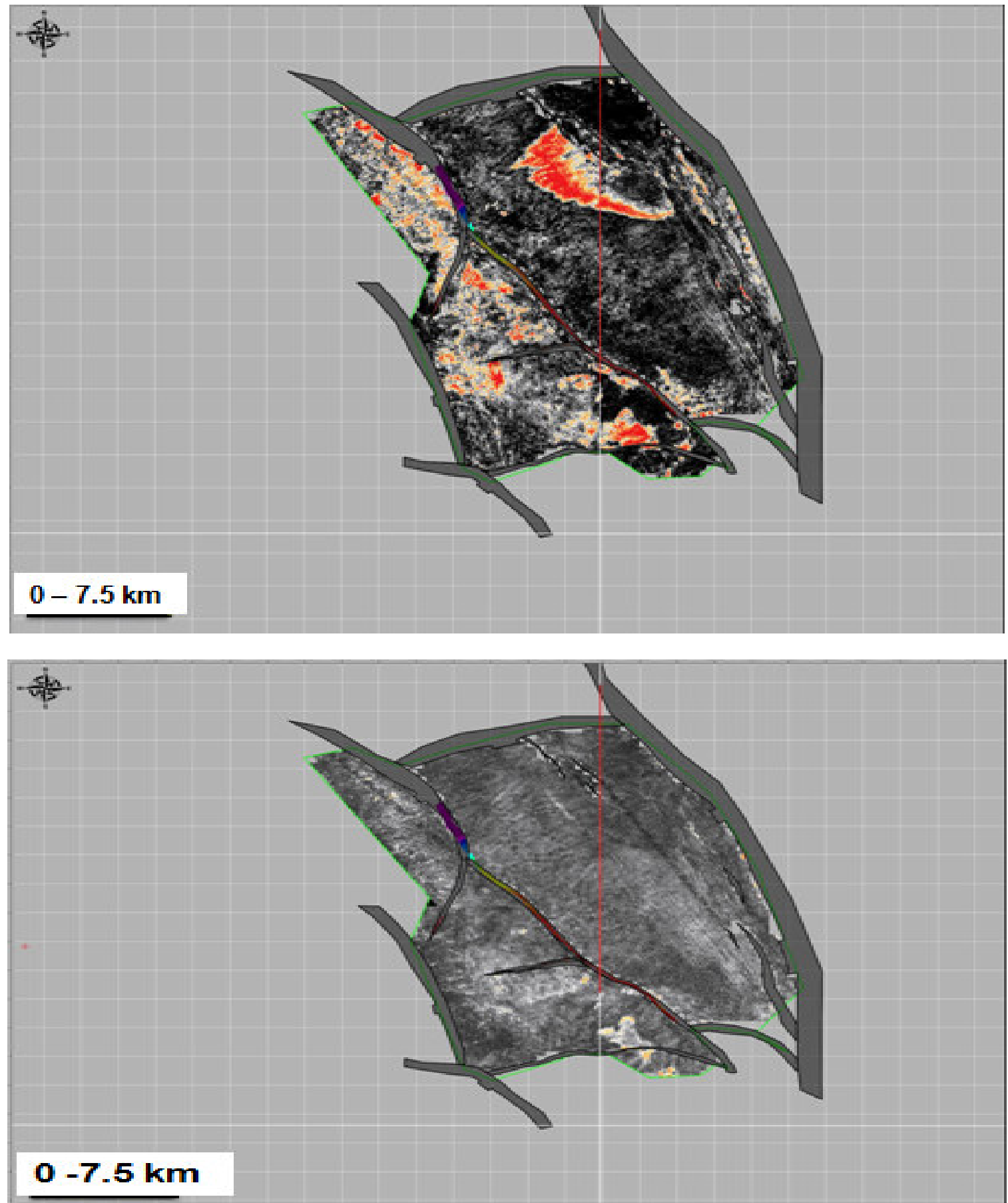

Figure 10: R.m.s maps of the top reservoir at $100 \mathrm{~ms}$ divided into two layers. Layer 1 (top) shows that nearly all the amplitude is concentrated on the first layer (at 50ms) and the amplitude wraps around fields A, B and C of Figure 5, against the dispersive amplitudes in the study area while Layer 2 (bottom) shows little amplitude presence at $50 \mathrm{~ms}$. 


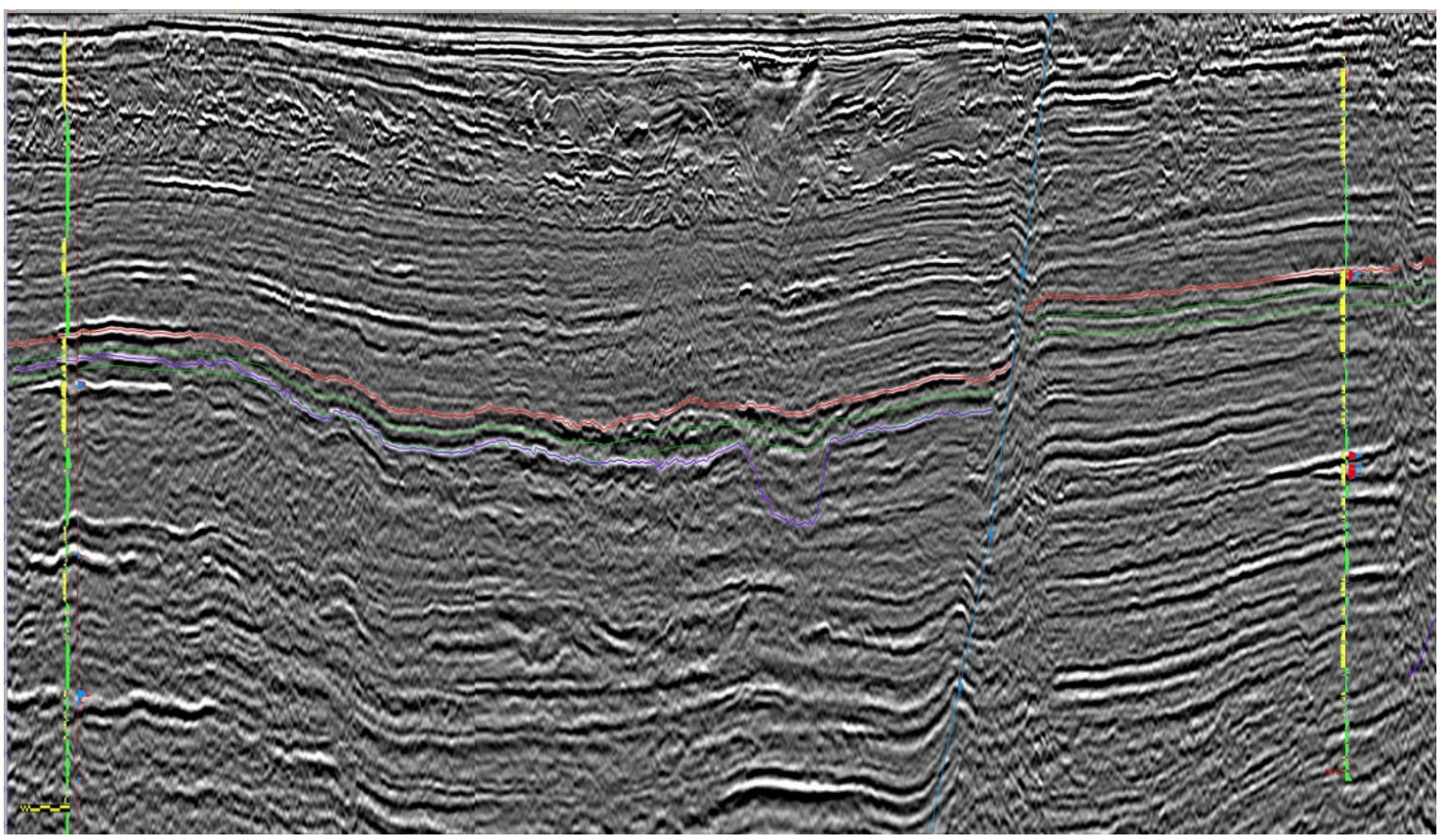

Figure 11: A section of the random line through the reference wells, A and C of fields $\mathrm{A}$ and

$\mathrm{C}$ respectively, showing the separation of the prospect by a regional growth fault into different compartment from well A, field A and into same compartment as well C, field C. The prospect and field C are fairly within the same depth.

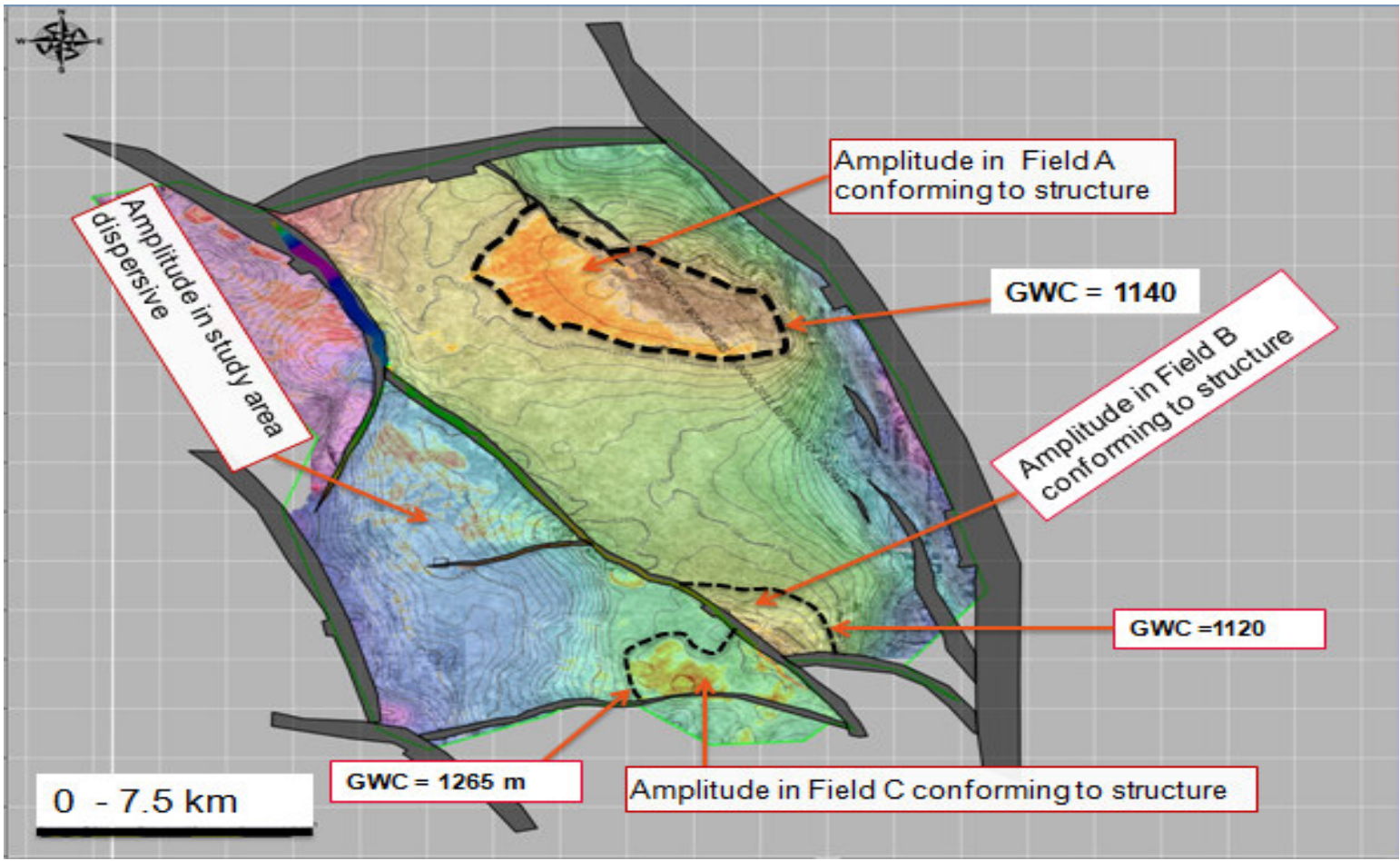

Figure 12: Top Reservoir Depth Structure Map (m) with fault boundaries showing the 3 fields, amplitudes variations and Gas - Water Contact (GWC) 


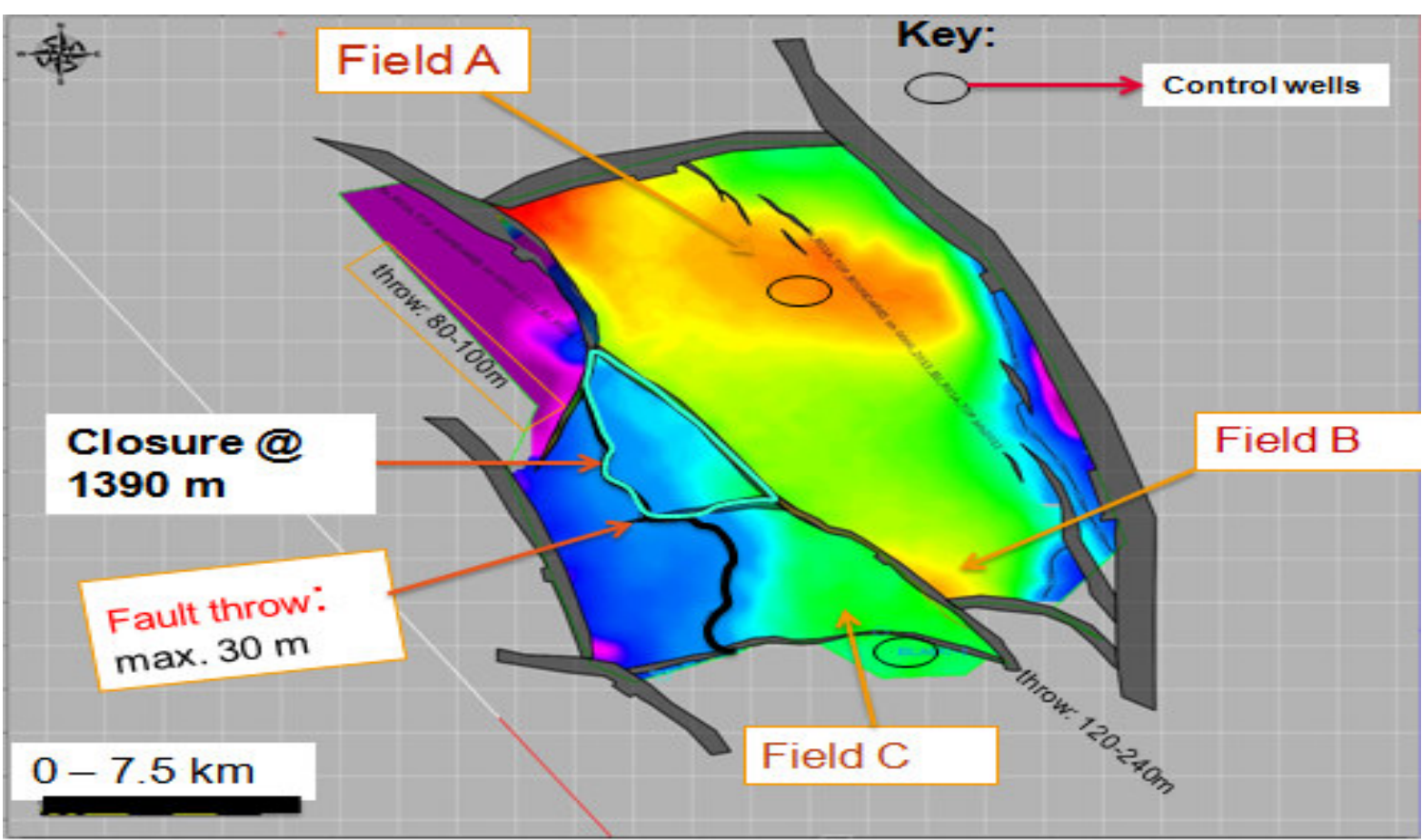

Figure 13: Depth structure map showing closure defined at 1390m for computation of Gross Rock Volume (GRV).

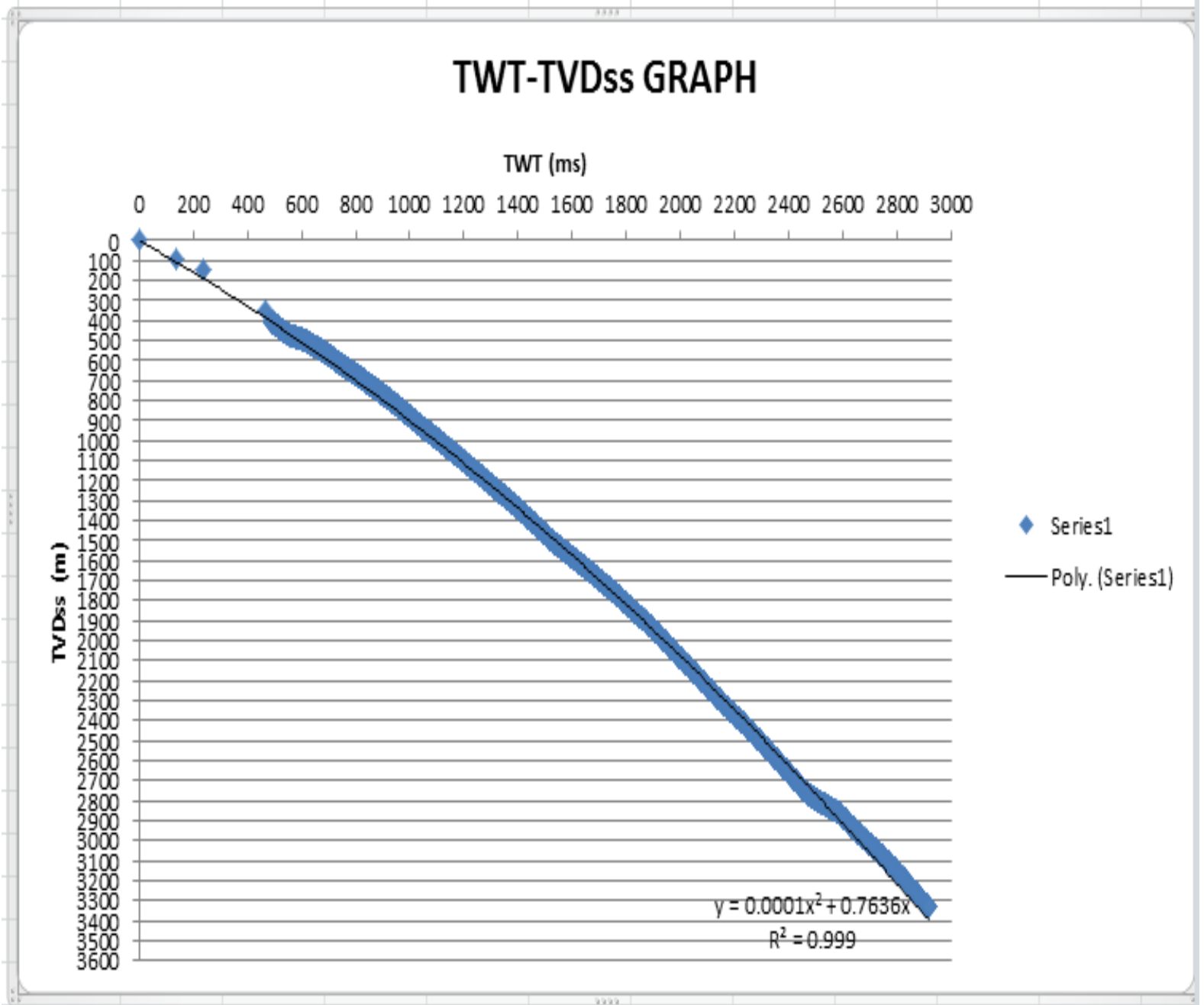

Figure 14: Time - Depth Curve : Velocity Model 


\subsection{Prospect Evaluation}

The trap is two-way dip against three faults. The main risk associated with this trap is the non-sealing N60 fault. The trap definition is based on interpreted boundary faults that delineate the prospect (Figure 13).

\subsubsection{Gross Rock Volume Estimation and Petrophysical Definition}

Gross Rock Volume (GRV) and petrophysical parameters such as Net to Gross ratio (NTG) and porosity are essential for the computation of hydrocarbon volumes. In this work, Gross Rock Volume (GRV) has been estimated based on the structure depth maps (m) shown in Figures 5 and 13 respectively. By using the available gamma ray log of well B in field C, the Net to Gross (NTG) ratios have been derived for in-place hydrocarbon resource calculations. Other petrophysical parameters are taken from R01C reservoir of Well B which is comparable to the prospect in terms of depth (a depth difference of $45 \mathrm{~m}$ between the top of R01A in field B and top of the prospect reservoir). A random line through the reference wells, A and B will show that, in terms of morphology the prospect is separated from field A into the same compartment as field C by the N150 regional fault. Well $\mathrm{A}$ in field $\mathrm{A}$ is at a much shallower level. A section of the random line through the reference wells, A and $\mathrm{C}$ of fields $\mathrm{A}$ and $\mathrm{C}$ respectively, shows the separation of the prospect by a regional growth fault into different compartment from well $\mathrm{A}$, field $\mathrm{A}$ and into same compartment as well $\mathrm{C}$, field $\mathrm{C}$. The prospect and field $\mathrm{C}$ are fairly within the same depth.

Methods used to obtain the required parameters are briefly illustrated below:

1. The Gross Rock Volume (GRV) is given by:

Gross Rock Volume $(\mathrm{GRV})=\mathrm{A} \times \mathrm{h}$

where $\mathrm{A}$ is the possible hydrocarbon bearing area $=22.25438 \mathrm{~km}^{2}$ and $\mathrm{h}$ is the gross reservoir mean thickness above the Hydrocarbon Water Contact $(\mathrm{HWC})=70 \mathrm{~m}$

$\mathrm{GRV}=1557.806600 \times 10^{6} \mathrm{~m}^{3}$

Net-to gross ratio was derived from resistivity and gamma ray logs of the analog from field $\mathrm{C}$ based on the approach adopted by Ala (2012):

$\mathrm{H}=$ Gross reservoir thickness

$\mathrm{G}=$ Gross pay thickness

$\mathrm{N} 1+\mathrm{N} 2+\mathrm{N} 3+\mathrm{N} 4=\mathrm{Net}$ reservoir thickness

$\mathrm{P} 1+\mathrm{P} 2+\mathrm{P} 3=$ Net pay thickness (includes rock above Hydrocarbon Water Contact)

Net-To-Gross ratio, NTG $=(\mathrm{N} 1+\mathrm{N} 2+\mathrm{N} 3) / \mathrm{G}$

2. Average porosity $(\phi)$ ratio of the pore space to total reservoir rock was estimated in view of the fact that, not the entire reservoir is pore spaced. Average porosity of reservoir, $\mathrm{R} 01 \mathrm{C}$ of field $\mathrm{C}$ is used. This is because the R01C reservoir is assumed in this study as the analog of R01A reservoir.

3. The relative saturation of hydrocarbon to water was also estimated as not all of the pore space contains hydrocarbon, part equally contains water. This fluid parameter is taken from R01C reservoir of field C.

5. The gas Formation Volume Factor (FVF) was obtained from the Pressure-Volume-Temperature (PVT) analysis in the laboratory. This parameter is essential for converting hydrocarbon volumes from reservoir (high temperature and pressure) to stock tank conditions. In this study, FVF of reservoir R01C of field $\mathrm{C}$ is equally used since the reservoir is assumed to be the analog of R01A.

6. Recovery Factor of the reservoir R01C reservoir of field $\mathrm{C}$ is also used for the volumetric computation.

\subsubsection{Recoverable Hydrocarbon Resources}

Based on the Gross Rock Volume and the petrophysical parameters already derived, Hydrocarbon (gas) volumes were computed by Deterministic Volumetric Method (DVM). The corresponding values of the parameters (from analog) used for calculations are given below:

Net $=63.72 \mathrm{~m}$; Gross $=70 \mathrm{~m} . \mathrm{NTG}=63.72 / 70=0.91$ (determined using gamma ray $\log )$

Porosity $(\phi)=25 \%$

Water Saturation $(\mathrm{Sw})=0.2$

Hydrocarbon Saturation $(\mathrm{Shc})=1-\mathrm{Sw}=1-0.2=0.8$

$1 /$ Gas Formation Volume Factor $(1 / \mathrm{Bg})=130$

Recovery Factor $(\mathrm{RF})=65 \%$

Then:

a. $\quad$ Net Pay Volume $(\mathrm{NPV})=\mathrm{GRV} \times \mathrm{NTG}=1557.806600 \times 10^{6} \times 0.91=1417.604006 \times 10^{6} \mathrm{~m}^{3}$

b. Net Pore Volume $(\mathrm{NPV})=\mathrm{GRV} \times \mathrm{NTG} \times \phi=1557.806600 \times 10^{6} \times 0.91 \times 0.25=354.4010015 \times 10^{6} \mathrm{~m}^{3}$

c. Net Hydrocarbon Pore Volume $(\mathrm{NHcPV})=\mathrm{GRV} \times \mathrm{NTG} \times \phi \times \mathrm{Shc}=1557.806600 \times 10^{6} \times 0.91 \times 0.25 \times$ $0.8=283.5208012 \times 10^{6} \mathrm{~m}^{3}$

d. Gas Initially In Place $(\mathrm{GIIP})=\mathrm{GRV} \times \mathrm{NTG} \times \phi \times \mathrm{Shc} \times 1 / \mathrm{Bg}=1557.806600 \times 10^{6} \times 0.91 \times 0.25 \times 0.8 \times$ $130=36.857704156 \times 10^{9} \mathrm{~m}^{3}=1301 \mathrm{bcf}$

e. Recoverable Reserves $(\mathrm{RR})=(\mathrm{GRV} \times \mathrm{NTG} \times \phi \times \mathrm{Shc} \times \mathrm{RF}) / \mathrm{Bg}=804.70874 \times 10^{6} \times 0.91 \times 0.25 \times 0.8 \times$ $0.65 \times 130=23.957507701399 \times 10^{9} \mathrm{~m}^{3}=846 \mathrm{bcf}$ 


\subsubsection{Risk Assessment}

In order to determine geologic success, numerical evaluation of risk has been performed on a play scale by considering the probability of existence of the following imperative geological factors: source rock, reservoir, trap, seal and charge (migration and timing). However, the overall chance of success of the prospect is tied to the following risk:

- Play Chance (\%) - which is common to all prospects, within the licensed zone

- Prospect Specific Risk (\%) - primarily due to changes in geology

The probability of geologic success is obtained by applying a simple mathematical relation:

Probability of Success $=\mathrm{P} 1 \times \mathrm{P} 2 \times \mathrm{P} 3 \times \mathrm{P} 4 \times \mathrm{P} 5$

Where,

$\mathrm{P} 1=$ Probability of presence of mature source rocks

P2 = Probability of presence of reservoir rocks

P3 = Probability of presence of Traps

P4 = Probability of Seals

P5 = Probability of Timing/Migration; taking into account the probabilities of occurrence of the above factors of play concept.

Modified risk assessment worksheet based on the approach of Otis and Schneidermann (1997) have been produced in Figure 15.

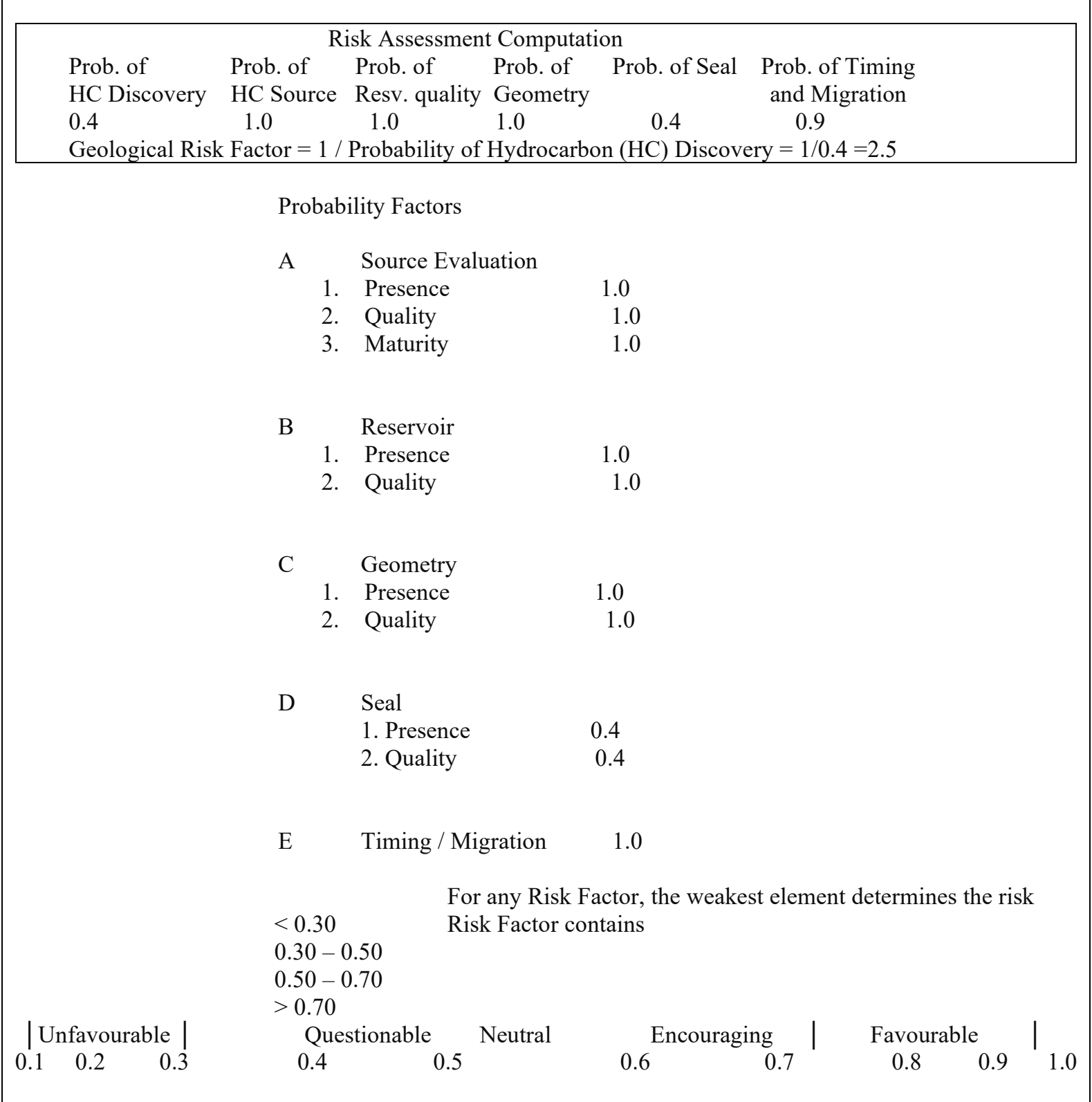

Figure 15: Risk assessment worksheet showing qualitative judgments on geologic risk 


\subsubsection{Risked Resources Estimation}

The probability of success (gas discovery) obtained in the risk assessment is given as 0.03456 . Estimated risked resources are obtained by multiplying the probability of success (hydrocarbon discovery) by the Original Gas in Place.

Hence Risked Resources = Probability of success $\times$ Gas Initially In Place

$$
=0.13824 \times 1301 \mathrm{bcf}=520 \mathrm{bcf}
$$

Also, Risked Recoverable Reserves $=$ Probability of success $\times$ Recoverable reserves

$$
=0.13824 \times 846 \mathrm{bcf}=338 \mathrm{bcf} \text {. }
$$

Assuming geologic success, only 520bcf of gas would be recovered from 338 bcf risked estimated gas resources. The summary of deductions from the analysis is given in the Table 1.

Table 1: Volumetric data and hypothetical volumetric estimates for the prospect that would be obtained if there was closure.

\begin{tabular}{|l|l|}
\hline Parameter & Value \\
\hline Sand & $70 \mathrm{~m}$ \\
\hline Gross Rock Volume (GRV) & $1557.8 \times 10^{6} \mathrm{~m}^{3}$ \\
\hline Net-to-gross & $91 \%$ \\
\hline Water saturation & $20 \%$ \\
\hline Gas Formation Volume Factor & $65 \%$ \\
\hline Porosity & $25 \%$ \\
\hline Gas Initially in Place & $1301 \mathrm{bcf}$ \\
\hline Recoverable reserves & $846 \mathrm{bcf}$ \\
\hline Risked estimated resources & $520 \mathrm{bcf}$ \\
\hline Risked recoverable reserves & $338 \mathrm{bcf}$ \\
\hline Recovery factor & 0.0076923076923 \\
\hline
\end{tabular}

\subsection{Conclusion}

This study has revealed that there is no closure in the study area due to fault seal failure. The N60 fault separating the prospect from field $\mathrm{C}$ has a small throw of $30 \mathrm{~m}$ maximum relative to the sand thickness of $70 \mathrm{~m}$. As a result, there is a 40m sand to sand juxtaposition across the N60 fault. This implies that the reservoir is hydrodynamically connected to downdip of field $\mathrm{C}$ which is in the water leg. As no borehole exists in the study area, it is impossible to determine reliably the Net-To-Gross (NTG) ratio of the reservoir from which additional information could be extracted on any seal possibility by clay smearing and / or cataclastic gouge generation within the fault zone. More so, amplitude extracted from the top reservoir and overlaid on structure depth map (Figure 12) indicates that amplitude distribution does not conform to structure. The amplitude expression is rather dispersive and regional. Some basic assumptions have been made in order to determine hydrocarbon volumes that would be obtained had the N60 fault been sealing and closure exist in reality. First, it is assumed that the N60 fault is sealing and therefore closure is hypothetically defined at contour $1390 \mathrm{~m}$ to close the structure against three faults. Based on this definition, the GRV was computed using SISMAGE. Second, it is further assumed that the fluid type in this reservoir is gas and petrophysical as well as fluid parameters (porosity, hydrocarbon saturation, recovery factor, and gas formation volume factor) required for the volumes calculations were taken from R01C reservoir of field $\mathrm{C}$ which is assumed as analog to the prospect. By applying volumetric method, the Gas Initially In Place (GIIP) was estimated at $1301 \mathrm{bcf}$ (Table 1). This volume has a recoverable equivalence of about $846 \mathrm{bcf}$. Risked estimated resources were equally obtained by multiplying the GIIP by the probability of success (0.4). Similarly, risked recoverable reserves were determined by multiplying the recoverable reserves by the probability of success. Detailed results of the net volumes, gas initially in place, recoverable gas, risked resources and risked recoverable gas are summarized in Table 1

\section{References}

Adeogba, A. A., McHargue, T. R. \& Graham, S. A. (2005). Transient fan architecture and depositional controls from near-surface 3-D seismic data, Niger Delta continental slope. .American Association of Petroleum Geologists Bulltein, 89, 627 - 643.

Aizebeokhai, A. P. \& Olayinka, I. (2011). Structural and Stratigraphic Mapping of Emi Field, Offshore Niger Delta. Journal of Geology and Mining Research, 3(2), 25 - 38.

Ajaegwu, N. E., Odoh, B. I., Akpunonu, E. O., Obiadi, I. I. \& Anakwuba, E. K. (2012). Late Miocene to Early Pliocene Palynostratigraphy and Palaeoenvironments of ANE - 1 Well, Eastern Niger Delta, Nigeria. Journal of Mining and Geology, 48(1), 31-43.

Ala, M. (2012). Petroleum Geology (Lecture / Presentation). M.Sc. Petroleum Geophysics, Imperial College London. 
Amigun, J. O., Olisa, B. and Fadeyi, O. O. (2012). Petrophysical analysis of well logs for reservoir evaluation: A case study of Laja Oilfield, Niger Delta. Journal of Petroleum and Gas Exploration, 2(10), 181-187.

Avbovbo, A. A. (1978). Tertiary Lithostratigraphy of the Niger Delta: American Association of Petroleum Geologists Bulletin, 62, 295-300.

Bank, N. (2012). Exploration Geoscience and Seismic Interpretation (Lecture/Presentation). M.Sc. Petroleum Geophysics, Imperial College London

Beka, F. T. \& Oti, M. N. (1995). The Distal Offshore Niger Delta: frontier prospects of mature petroleum province. In Oti, M. N. and Postma, G., Geology of Deltas: Rotherdam, A. A. Balkema, p. 237-241

Cohen, H. A. \& McClay, K. R. (1996). Niger Delta shale tectonics. Marine and Petroleum Geology, 13, 313-328.

Damuth, J. E. (1994). Neogene gravity tectonics and depositional processes on the deep Niger Delta continental margin. Marine and Petroleum Geology, 11, 320-346.

Doust, H. (1989). The Niger Delta Hydrocarbon Potential, a major Tertiary Niger Delta Province. Proceedings of KNGMG symposium, Coastal Lowstands, Geology and Geotechnology, The Hague, Nehterlands. Kluiver Academic Publishers, Dordrecht, 203-204.

Doust, H. \& Omatsola, E. (1990). Niger Delta. In Edwards, J. D. and Santogross, P. A., Divergent / Passive margin Basins. AAPG Memoir. American Association of Petroleum Geologists, Tulsa, OK, 48, 239-248.

Drecun, R. \& Lucas, J. (1985). Enhancement of edge patterns on horizontal time slices. $55^{\text {th }}$ Annual International Meetings, SEG, Expanded Abstract, pp.579 - 582.

Ejedawe, J. E., Coker, S. J. L., Lambert-Aikhionbare, D. O., Alofe, K. B. \& Adoh, F. O. (1984). Evolution of oil generative window and oil and gas occurrence in Tertiary Niger Delta Basin. American Association of Petroleum Geologists Bulletin, 68, 1744-1751.

Emujokporue, C. N. \& Nwosu, I. (2012). Integration of well Logs and Seismic Data for Prospect Evaluation of an X Field, Onshore Niger Delta, Nigeria. International Journal of Geosciences, 3(4A), 872-877.

Evamy, B. D., Haremboure, J., Kamerling, P., Knaap, W. A., Molloy, F. A. and Rowlands, P. H. (1978). Hydrocarbon Habitat of Tertiary Niger Delta. American Association of Petroleum Geologists Bulletin, 62, 277-298.

Haack, R. C., Sundararaman, P. \& Dahl, J. (1997). Niger Delta Petroleum System. In Extended Abstracts, AAPG/ABGP Hedberg Research Symposium, Petroleum System of the South Atlantic Margin, November 16 -19, 1997, Rio de Janeiro, Brazil.

Heiniom P. \& Daviesm R. J. (2006). Degradation of compressional fold belts: Deep-water Niger Delta. American Association of Petroleum Geologists Bulletin, 90(5), 753-770.

Hooper, R. J., Fitzsimmons, R. J., Grant, N. \& Vendeville, B. C. (2002). The role of deformation in controlling depositional patterns in the South-Central Niger Delta, West Africa. Journal of Structural Geology, 24(2002), 847-859.

Hospers, J. (1965). Gravity field and structure of the Niger Delta, Nigeria, West Africa. Geological Society of African Bulletin, 76, 407-422.

Jakubowicz, H. (2013). Advance Seismic Methods (Lecture / Presentation). M.Sc. Petroleum Geophysics, Imperial College London

Kadafa, A. A. (2012). Oil Exploration and Spillage in the Niger Delta of Nigeria.Civil and Environmental Research, 2(3), 38-43.

Kaplan, A., Lusser, C. U. \& Norton, I. O. (1994). Tectonic map of the World. Panel 10: Tulsa, American Association of Petroleum Geologists, scale 1: 10, 000, 000.

Knox, G. J. \& Omatsola, E. M. (1987). Development of the Cenozoic Niger Delta in terms of the Escalor Regression model and impact on hydrocarbon distribution. In Van der Linden, W. J. M.; Cloetingh, S. A. P. L; Kaasschieter, J. P. K.; Van der Gun, J. A. M. Proceedings of the KNGMG Symposiums Coastal Lowlands, Geology and Geotechnology: Kluwer, Academic Publishers, Dordrectt. Pp.181-202.

Kulke, H. (1995). Nigeria. In Kulke, H., ed., Regional Petroleum Geology of the World. Part II: Africa, America, Australia and Artarctica: Berlin, Gebruder Borntraeger, Pp. 143-172.

Lehner, P. \& De Ruiter, P. A. C. (1977). Structural history of Atlantic margin of Africa. American Association of Petroleum Geologists Bulletin, 61, 961-981.

Merki, P. I. (1972). Structural Geology of Cenozoic Niger Delta. Proceedings of First African Regional Conference 1970, Ibadan University Press, Ibadan, Nigeria. Pp. 251-266.

Opara, A. I. (2010). Prospectivity Evaluation of Usso Field, Onshore Niger Delta Basin, using 3-D Seismic and Well Log Data. Petroleum and Coal, 52(4), 308-313.

Opara, A. I., Anyiam, U. O. \& Nduka, A. V. (2011). 3-D Seismic Interpretation and Structural Analysis of Ossu Oilfield, Northern Depobelt, Onshore Niger Delta, Nigeria. The pacific Journal of Science and Technology, 12(1), 502-508.

Otis, R. M. \& Shneidermann, N. (1997). A process for Evaluating Exploration Prospects. American Association of Petroleum Geologists Bulletin, 81 (7), 1087-1109. 
Owoyemi, A. O. \& Wills (2006). Depositional patterns Across Syndepositional Normal Faults, Niger Delta, Nigeria. Journal of Sedimentary Research, 76, 346-363.

Reijers, T. J. A. (2011). Stratigraphy and Sedimentology of the Niger Delta.Geologos, 17(3), 133-162.

Reijers, T. J. A., Petters, S. W. \& Nwajide, C. S. (1997). The Niger Delta Basin. In Selley, R. C., ed., African Basins: Sedimentary Basins of the World, Elservier, 3, 143-172.

Short, K. C. \& Stauble, A. J. (1965). Outline of geology of Niger Delta. American Association of Petroleum Geologists Bulletin, 51, 761-779.

Stacher, P. (1995). Present Understanding or Delta Hydrocarbon Habitat. In Oti, M. N. and Postma, G., eds., Geology of Deltas: Rotterdam, A. A. Balkema, p. 257-267.

Tuttle, M. L. W., Charpentier, R. R. \& BrownField, M. E. (1999). The Niger Delta Province, Nigeria, Cameroon, Equatorial Guinea, Africa. Open file Report, 99-50-H: United States Geological Survey, Washington, D.C. Pp.44.

Weber, K. J. (1987). Hydrocarbon distribution patterns in Nigerian growth fault structures controlled by structural style and stratigraphy. Journal of Petroleum Science and Engineering, 1, 91-104.

Whiteman, A. (1982). Nigeria: its Petroleum Geology, Resources and Potential. London, Graham and Trotman Press.

Xiao, H. \& Suppe, J. (1992). Origin of Rollover. American Association of Petroleum Geologists Bulletin, 76, 509229. 